\title{
Immediately loaded post-extraction implant associated with connective grafting envelope-flap: A case report
}

\author{
Giuseppe Fiamminghi ${ }^{1 *}$, Daniele Pio Urbano ${ }^{2}$, Riccardo Botta ${ }^{3}$, Luca Viganò ${ }^{4}$ and Cinzia Casu \\ ${ }^{1}$ President of TIDE, Private Dental Practice, Parma, Italy \\ ${ }^{2}$ Vice President of TIDE, Private Dental Practice, Parma, Italy \\ ${ }^{3}$ Departement of Dentistry, IRCSS San Raffaele Hospital, Dental School, University of Mi- lano, Milano, Italy \\ ${ }^{4}$ Departement of Radiology, San Paolo Dental Building, University of Milan, Milano, Italy \\ ${ }^{5}$ Private Dental Practice, Cagliari, Italy
}

\begin{abstract}
Immediately loaded post-extraction implants are a valid therapeutic alternative to traditional implantology, if used in well-selected cases and following a specific surgical-prosthetic protocol. In this case, following a vertical fracture, an upper left lateral incisor was replaced with an immediately loaded post-extraction implant.

3 months later, after osseointegration, it was decided to place an epithelial-connective tissue graft after epithelium removal, with envelope flap, in order to thicken the tissues and prevent the physiological contraction (about $1 \mathrm{~mm}$ ) that is found in the first year after loading.
\end{abstract}

\section{Introduction}

Approximately in the mid-80s, at the same time of the development of traditional connective tissue grafting techniques, defined as bilaminar or subepithelial [1] the envelope variant of the procedure was introduced by Raetzke [2].

After a long time period it was then revalued thanks to the advent of minimally-invasive surgical techniques.

Even over time in the literature have emerged evidence of greater increase in post-treatment keratinized tissue, not to be confused with a greater percentage of root coverage with the en - velope technique compared to the bilaminar one associated with the coronally positioned flap [3].

When we speak of a connective tissue grafting we mean a collection of epithelial-connective tissue to which the epithelial component is removed, whose donor site is identifiable in fibro - mucous palatine, rich in dense connective tissue. Unlike Trap-Door technique, where a partial thickness primary flap is raised and after the deep connective tissue extraction has been car- ried out, the "door" is closed, creating a healing by first intention, the epithelial-connective technique, which it plans to withdraw the gingival tissue in full while creating a second inten - tion healing, it allows to incorporate into the graft a more stable and dense tissue which undergoes less contraction in time.

Furthermore, since the collection is reduced in thickness, bleeding is minimal, pain is almost absent and healing is very rapid.

According to a recent study [4], the post-operative course of patients treated with the two different techniques showed no significant differences. However at 1 year from surgery, patients treated with the connective tissue grafting technique achieved an increase greater than gingival thickness compared to those with the Trap-Door technique.
Going more specifically when applying these techniques to implantology we must take into account the differences between the peri-implant tissues compared to those surrounding the natural teeth.

The first one are certainly less resistant to mechanical or microbiological irritation agents, due to the lower blood supply, the different course of periodontal fibers and a higher percentage of collagen fibers and lower fibroblasts, which make it resemble a scar tissue [5].

\section{Case presentation}

A 25-year-old male patient, ASA I and smoker was referred to our attention with a fractured left upper lateral incisor (Figure 1).

After evaluating different therapeutic options, it was decided to extract the tooth and place an immediately loaded implant. (Figure 2).

After a period of three months to obtain the osseointegration of the implant and the healing of the peri-implant soft tissues, already conditioned by the immediate provisional (Figure 3), the case has been carefully reevaluated on the aesthetic level.

In the context of an implant therapy is immediately evident that the key for an excellent ae- sthetic result is an harmonic profile of the soft tissue.

Harmony can be defined as what is beautiful in our eyes from an aesthetic point: only if the profile of the soft tissue is harmonious the

${ }^{\star}$ Correspondence to: Giuseppe Fiamminghi, President of TIDE, Private Dental Practice, Parma, Italy, Tel: 0521.674093; E-mail: giuseppefiamminghi@gmail.com

Key words: post-extraction implants, biotype conversion, immediate loading, connective epithelial sampling

Received: October 03, 2018; Accepted: October 12, 2018; Published: October 15,2018 
technician will be able to transfer this balance to the shape of the teeth. So we have to maintain all this over time; in this way implant rehabilitation can be defined as a successfully treatment [6].

Following careful evaluation of the case, perimplant soft tissue after three months from the first surgery are harmonic, but very thin and therefore will certainly meet over the years to a recession thus creating an imperfection of our rehabilitation. (Figure 4) [7,8].

For this reason, in agreement with the patient, a graft of connective tissue was provided. In order to reduce its invasiveness and to optimize time and results, was performed with the envelope technique. (Figure 5)
An intrasulcular incision is then extended to partial thickness in the mesial and distal apical direction to create a true envelope within which the previously performed graft is inserted.

6 months after grafting, the case was finalized with a zirconiumceramic crown (Figure 6) .

\section{Discussion and conclusions}

As we can see from the final pictures and also at 4 years from the finalization of the case (Figure 7), we have obtained a conversion of the biotype from thin to thick contrasting the physiological recession of the

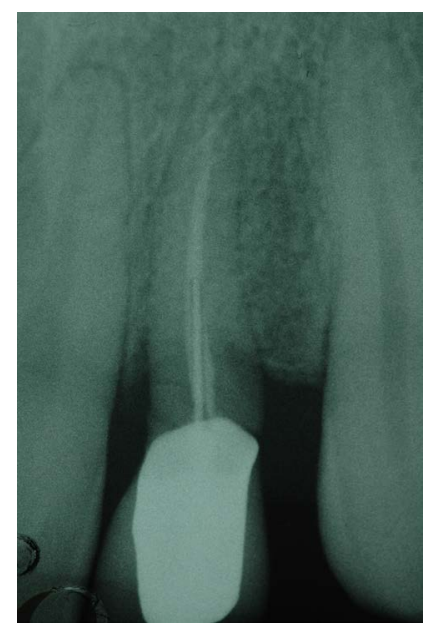

Figure 1. ASA I and smoker was referred to our attention with a fractured left upper lateral incisor
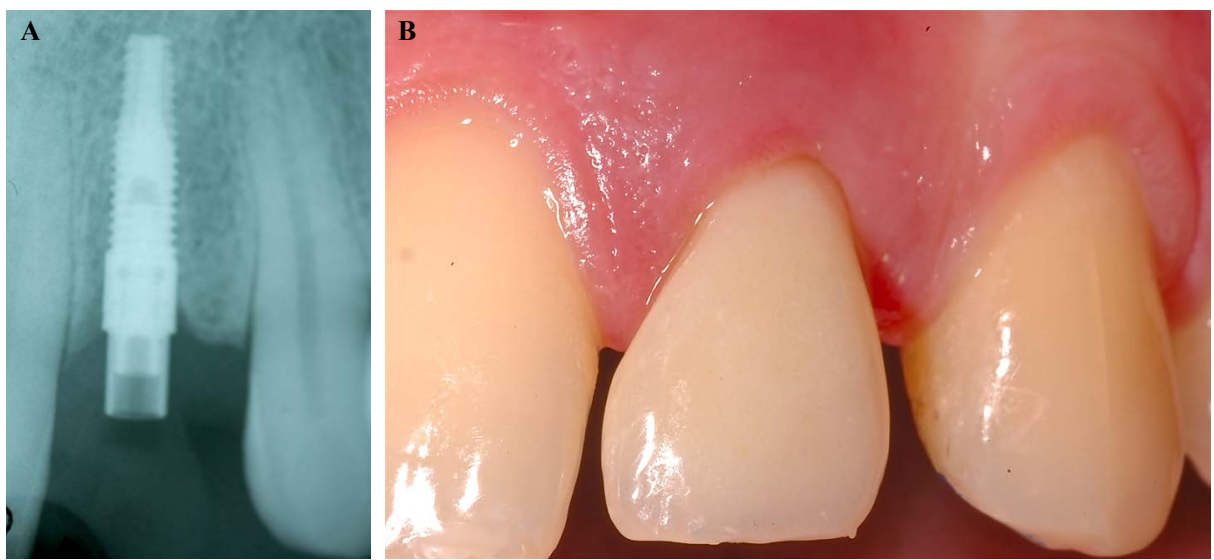

Figure 2. After evaluating different therapeutic options, it was decided to extract the tooth and place an immediately loaded implant
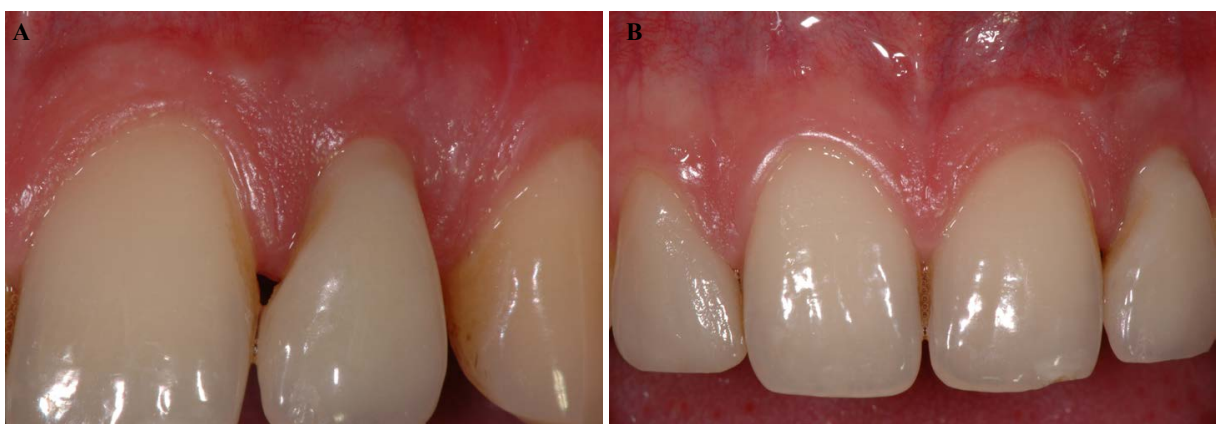

Figure 3. After a period of three months to obtain the osseointegration of the implant and the healing of the peri-implant soft tissues, already conditioned by the immediate provisional 


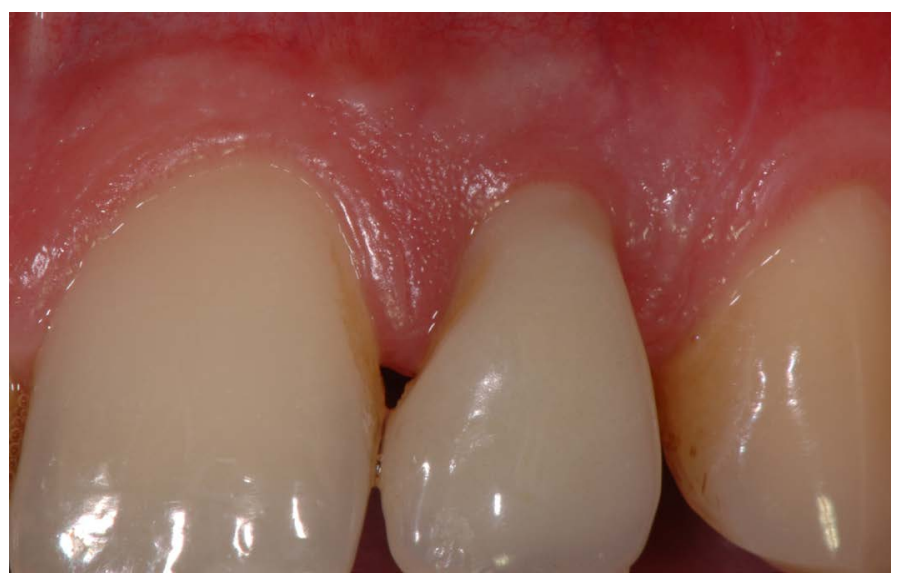

Figure 4. perimplant soft tissue after three months from the first surgery are harmonic, but very thin and therefore will certainly meet over the years to a recession thus creating an imperfection of our rehabilitation

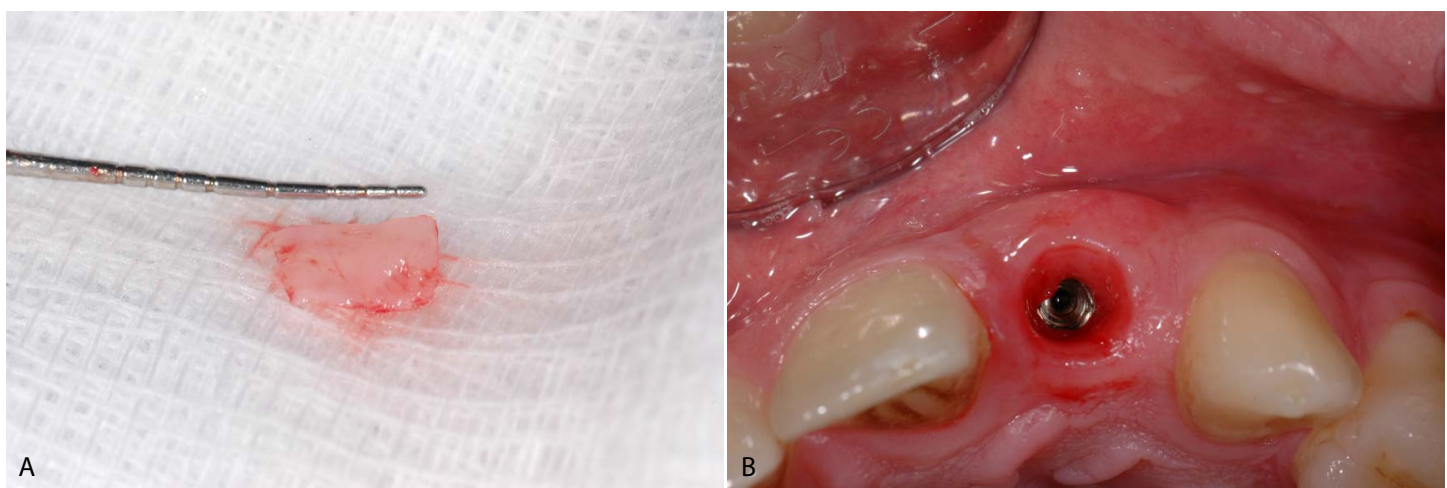

Figure 5. In agreement with the patient, a graft of connective tissue was provided. In order to reduce its invasiveness and to optimize time and results, was performed with the envelope technique
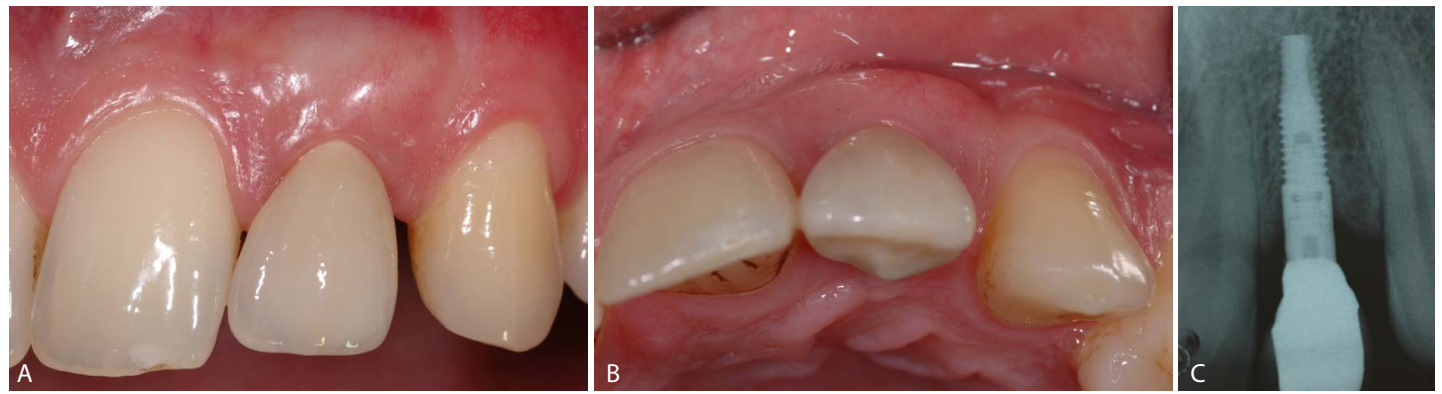

Figure 6. 6 months after grafting, the case was finalized with a zirconium-ceramic crown

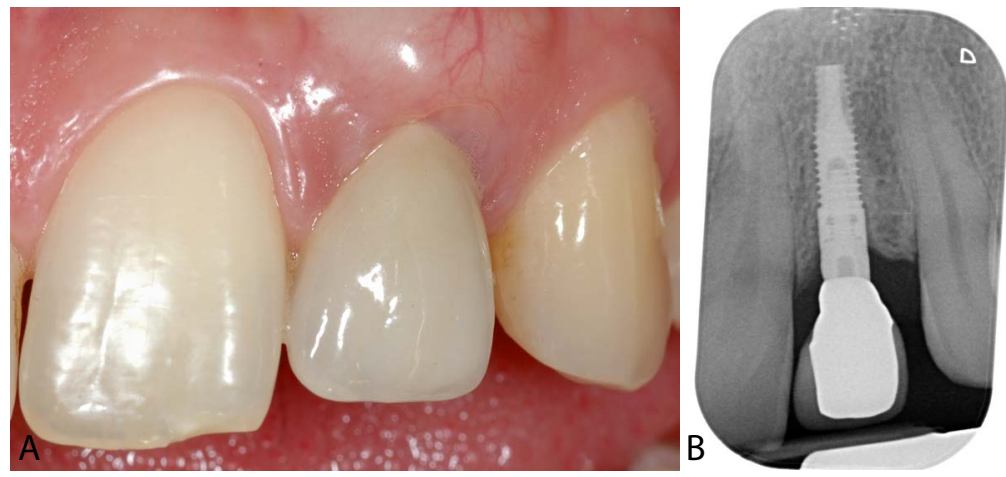

Figure 7. After 4 years from the finalization of the case 
soft tissues that occurs as a result of our surgical acts. Also providing formation of biological width and achieved an aesthetic result easily to maintain over time, we can therefore define as successful therapy [9].

It should not be forgotten that the results are achievable thanks to a correct implant placement for the growth of soft tissues in the interpapillary spaces and for the maintenance of the buccalplate, on which the vestibular aspect of our tissues will depend [10,11].

Lastly, it is useful to remember that according to a Burkhardt study the percentages success of recessions coverage are $95 \%$ on natural teeth, while on implants they fall to $66 \%$ at 6 mon - ths after surgery [12].

We have decided to document this case to provide a valid alternative to conventional immediate load implant treatment, where the aesthetic result is not completely satisfactory. The technique proved to be safe and effective.

\section{References}

1. Langer B, Langer L (1985) Subepithelial connective tissue graft technique for roo coverage. J Periodontol 56: 715-720. [Crossref]

2. Raetzke PB (1985) Covering localized areas of root exposure employing the "envelope" technique. J Periodontol 56: 397-402. [Crossref]

3. Cordioli G, Mortarino C, Chierico A, Grusovin MG, Majzoub Z (2001) Comparison of 2 techniques of subepithelial connective tissue graft in the treatment of gingival recessions. J Periodontol 72: 1470-1476. [Crossref]
4. Zucchelli G, Mele M, Stefanini M, Mazzotti C, Montebugnoli L de Sanctis M (2010) Patient Morbidity and root coverage outcome after subepithelial connective tissue and de-epithelized grafts. A comparative controlled randomized trial, $J$ Clin Periodontol 37: 728-738.

5. Moon IS, Berglundh T, Abrahamsson I, Linder E, Lindhe J (1999) The barrier between the keratinized mucosa and the dental implant. An experimental study in the dog. J Clin Periodontol 26: 658-663. [Crossref]

6. Fürhauser R, Florescu D, Benesch T, Haas R, Mailath G, et al. (2005) Evaluation of soft tissue around single-tooth implant crowns: the pink esthetic score. Clin Oral Implants Res 16: 639-644. [Crossref]

7. Buser D, Chappuis V, Bornstein MM, Wittneben JG, Frei M, et al. (2013) Long term stability of contour augmentation with early implant placement following single tooth extraction in the esthetic zone: a prospective, cross-sectional study in 41 patients with a 5-to 9 year follow-up. J Periodontal 84: 1517-1527.

8. Chen St, Buser D (2014) esthetic outcomes following immediate and early implant placement in the anterior maxilla-a systematic review. Int $J$ Oral Maxillofacial Implants 29: 186-2015.

9. Kan JY, Rungcharassaeng K, Lozada JL (2005) Bilaminar subepithelial connective tissue grafts for immediate implant placement and provisionalization in the esthetic zone. J Calif Dent Assoc 33: 865-871.

10. Tarnow D, Elian N, Fletcher P, Froum S, Magner A, et al. (2003) Vertical distance from the crest of bone to the height of the inter proximal papilla between adjacent implants. J Periodontal 71: 546-549.

11. Tarnow DP, Cho SC, Wallace SS (2000) The effect of inter-implant distance on the height of inter-implant bone crest. J Periodontol 71: 546-549. [Crossref]

12. Burkhardt R, Joss A, Lang NP (2008) Soft tissue dehiscence coverage around endosseous implants: a prospective cohort study. Clin Oral Implants Res 19: 451-457. [Crossref]

Copyright: $@ 2018$ Fiamminghi G. This is an open-access article distributed under the terms of the Creative Commons Attribution License, which permits unrestricted use, distribution, and reproduction in any medium, provided the original author and source are credited. 